\title{
EDITORIAL
}

\section{Psyche and history}

Addressing the American Historical Association in 1958, William L. Langer emphasized that the psychological effects of the Black Death were a significant historical phenomenon and he proposed that the matter be studied by the methods of psychoanalysis. Since then the psychological aspects of historical events and personages have increasingly attracted attention, indeed to such an extent that this area of interest has received a specific designation, 'psychohistory'. As this interest has grown two problem areas have come under investigation.

One area encompasses the psychological impact of disease, particularly that produced by major or recurrent epidemics. This problem is important, not only in its own right, but also because it is a part of the larger problem of the affective history of societies and communities. Actually, the historical investigation of such problems is not completely new. One need only recall Hecker's (1832) study of the medieval dance frenzy, Crawfurd's study of 1914 on plague and pestilence in literature and art, and D'Irsay's examination in 1927 of defence reactions during the Black Death. Nonetheless, such studies were sporadic, so that a large and potentially important area of research still remains to be worked.

Useful approaches to this problem area have more recently come from several different directions. One has been the use of pictorial evidence to demonstrate a change in the psychological state of a social group over a period of time. Millard Meiss, in his study of painting in Florence and Siena after the Black Death, showed that changes in art which occurred after the epidemic were due to the establishment of a new state of mind among the people of these cities (Meiss, 1951). Employing a similar approach, but on a much larger scale, and utilizing a wide range of literary and visual sources, Alberto Tenenti (1957) explored psychological attitudes toward life and death in Italy and France during the Renaissance.

More provocative is the work of René Baehrel (1951), who pointed out that from a psychological viewpoint the period during which an epidemic prevails is a period of fear, of anxiety, and may be compared with and studied like periods of revolutionary terror. Indeed, Baehrel suggested that psychological attitudes developed in earlier epidemics and famine periods were latently available during the terror of the French Revolution. Moreover, he also argued that in such psychological climates social class antagonisms, religious animosities, and other hostile attitudes towards individuals and groups may be activated and realized in violent behaviour. This thesis had already been illustrated by Seraphine Guerchberg (1948) in her study of the controversy over the alleged plague sowers and the massacre of Jews on this ground at the time of the Black Death.

The broad framework within which studies, such as those of Baehrel and Tenenti, must be seen and from which they derive in part was set forth in 1941 by the French historian, Lucien Febvre. In this programmatic statement he urged historians to turn their attention to the emotional life of men in their social environment and to reconstruct it on the basis of its manifestations as indicated by available evidence. The evidence might be provided by a variety of sources, not only written records. For example, one might study how words were used at different periods, what words were available to what groups, and the like. A second source suggested by Febvre was iconography; a third was literature; and still another was provided by legal cases and documents. In short, any evidence that throws light on individual and collective psychology. In this sense Febvre envisaged a history of love, of pity, of cruelty, of death. How this programme was actually applied may be seen in his masterly work on the religion of Rabelais, where he showed on the basis of empirical evidence what sixteenth-century men could have experienced and considered thinkable in relation to the supernatural (Febvre, 1942). This is psychohistory on a conscious level, where the historian is aware 
that analysis of the manifest content of ideas and beliefs and of the modes of expression, the intensity of emotional relationships, and the selective valuation placed on different kinds of relationships reflects a certain psychological organization. Such aspects are indicative of the psychological make-up up and modes of behaviour of individuals and groups in relation to the larger structure of social and cultural life. Historical periods are characterized by different sensibilities-that is, modes of feeling shared in varying degree by those living at a particular time. An awareness that the personal and the public interpenetrate within the framework of society must underlie any endeavour to understand these psychological aspects. Individuals and groups cannot be divorced from the larger institutions within which they carry on their lives, since it is within this framework that their psychologies are formulated. The way in which an individual in a given historical period perceives his world, the feeling he has about it, depends on his interests, beliefs, and values, on the intricate connections between his inner life, his life-pattern, and the specific social and cultural conditions which he encounters in his environment. This characteristic mode of perceiving and feeling which we call sensibility is an expression of the way in which the personality integrates these diverse elements. Such relationships are as complex for groups as they are for individuals. In any given historical period, a society or a group within it may exhibit a characteristic pattern of emotional attitudes. A prevalent psychological orientation of this kind, which by analogy with Whitehead's idea of a climate of opinion can be called an emotional climate, develops out of social and cultural conditions specific to a society or group and is related to its historical development. Numerous individual sensibilities contribute to an emotional climate, and in turn the prevalence of such a complex of feelings tends to stimulate individuals and groups to perceive their socio-cultural environment, the various aspects of society, along certain lines and to act in characteristic ways. ${ }^{1}$

Against this background may be set the other current psychohistorical area of interest, the use of psychological models to understand historical individuals, particularly leaders of various types in terms of the interplay between public performance and private personality. This endeavour has also had earlier antecedents in the form of so-called pathographies-for example, Möbius's case history of Rousseau (Möbius, 1889), and Lange's of Hölderlin (Lange, 1909). Indeed, Jaspers tried to show how the neurotic drives of his subjects contributed to their creative accomplishments (Jaspers, 1922). These biographical studies were in essence case histories undertaken by psychiatrists or those with psychiatric orientations. Freud's discoveries and ideas were applied very early to biographical material, indeed by Freud himself as in Eine Kindheitserinnerung des Leonardo da Vinci and other contributions. Most of these early contributions were relatively crude and were frequently vitiated by the fallacy of unilateralism-that is, by an effort to establish a one to one relationship between traumatic early experiences and later behaviour, as for instance in the Bullitt-Freud analysis of Woodrow Wilson. Probably the most successful practitioner so far has been Erik Erikson with his studies of Luther and Gandhi (Erikson, 1958, 1969, respectively). But Erikson's work illustrates both some possibilities and limitations. Two points will clarify the limitations. Erikson begins his study of Luther with a story of the young monk having had a fit, a story for which there is no good evidence. Nevertheless, he used the story, justifying his practice on the ground that if it didn't happen, it as good as happened. But unfortunately Erikson gives no criteria indicating when and where he would admit rumour and legend as evidence, and when he would not. Another point is Erikson's emphasis on Luther's anality, apparently overlooking the fact that the whole tone of life and its expression in the sixteenth century was coarse. Cursing, belching, farting, gluttony, and rude behaviour were common at all levels of society, the highest as well as the lowest, certainly in Germany if one is to judge from the testimony of visitors such as Machiavelli in 1508.

There is no doubt that psychohistorical studies in the biographical area offer rich potentialities, and there are a few outstanding contributions, such as Starobinski's elegant and subtle analysis of the tensions in Rousseau's personality and their relation to his ideas and activities (Starobinski, 1958). However, if the potentialities of psychohistory are to be realized, certain points must be emphasized.

1For a development of these concepts and their application as analytic tools, see Rosen, G. (1967). 
In modern history and biography, the study of process is pre-eminent. We want to see the character forming, its singularities taking shape in relation to the inner drives and compulsions. The task of the historian is to represent convincingly internal processes, pressures, and changes and thus to map out the elements that produced the phenomenon he confronts. To do this it is necessary first of all to be aware of the historical period. It is not enough to know about Luther; one must also know the sixteenth century and its varied aspects.

One must also beware of the reductionist fallacy - that is, not to reduce an individual to his psychic traumata and weaknesses. This is one of Erikson's considerable achievements, his portrayal of Luther's transformation of his weakness into spiritual power which enabled so many of his contemporaries to identify with him.

Historians have available to them a field of high interest in the investigation of collective and individual psychology in relation to historical developments. Huizinga showed some 40 years ago that the fifteenth century in Europe was a period of melancholy and morbid introspection, but he saw this as a phenomenon of cultural history. But we may also look at it as a problem of psychopathology in a period of cultural change, in which individuals and groups participated. These are some of the possibilities that exist for those who wish to study such problems (Rosen, 1968).

GEORGE ROSEN

\section{REFERENCES}

Bachrel, R. (1951). Épidémic et terreur: Histoire et sociologie Annales Historiques de la Révolution Francaise, 23, 113-146.

Crawfurd, R. H. P. (1914). Plague and Pestilence in Literature and Art. Clarendon Press: Oxford.

D'Irsay, S. (1927). Defence reactions during the Black Death, 1348-1349. Antials of Medical History, 9, 169-179.

Erikson, E. H. (1958). Young Man Luther. A Study in Psychoanalysis and History. W. W. Norton: New York.

Erikson, E. H. (1969). Gandhi's Truth: On the Origins of Militant Nonviolence. W. W. Norton: New York.

Febvre, L. (1941). La sensibilité et l'histoire, Ammales d'Histoire Sociale, 3, 5-20.

Febvre, L. (1942). Le Problème de IIncroyance au XVIe Siècle, la Religion de Rabelais. Édition revue. Michel: Paris, 1962 (originally published 1942).

Guerchberg, S. (1948). La controverse sur les prétendus semeurs de la "Peste Noire", d"après les traités de peste de l'époque. Revue des Études Juives, N.S., 8, 3-40.

Hecker, J. F. K. (1832). Die Tanzwuth, eine Volkskrankheit im Mittelutter. T. C. F. Enslin: Berlin.
Jaspers, K. (1922). Strindberg und Van Gogh. Versuch einer pathographischen Analyse unter vergleichender Heranzichung von Swedenborg und Hölderlin. E. Bircher: Leipzig.

Lange, W. (1909). Hölderlin, eine Pathographie mit zwölf Schriftproben und einer Stammtafel. F. Enke: Stuttgart.

Langer, W. L. (1958). The next assignment. American Historical Review, 63, 283-304.

Meiss, M. (1951). Painting in Florence and Siena after the Black Death. Princeton University Press: Princeton, N.J.

Möbius, P. J. (1889). J. J. Rousseau's Krankheitsgeschichte. F. C. W. Vogel : Leipzig.

Rosen, G. (1967). Emotion and sensibility in ages of anxiety; a comparative historical review. American Journal of Psychiatry, 124, 771-784, 1967.

Rosen, G. (1968). Madness in Society. Chapters in the Historical Sociology of Mental lliness. Routledge: London.

Starobinski, J. (1958). Jean-Jacques Rousseau, la Transparence et l'Obstacle. Plon: Paris.

Tenenti, A. (1957). Il Senso della Morte e l'Amore della Vita nel Rinascimemo. Francia e llalia. Einaudi: Torino. 